\title{
Computer modelling of the sinoatrial node
}

\section{Ronald Wilders}

Published online: 7 June 2007

(C) International Federation for Medical and Biological Engineering 2007

\section{Erratum to: Med Bio Eng Comput DOI 10.1007/s11517-006-0127-0}

Due to a processing error, the presentation of some URL's in Paragraph 4.1 and Table 4 was incorrect.

The correct URL's are given below http://nsr.bioeng.washington.edu/ http://rudylab.wustl.edu/ http://personalpages.umist.ac.uk/staff/H.Zhang-3/ http://arrhythmia.hofstra.edu/ http://ssd1.bme.memphis.edu/icell/ http://cor.physiol.ox.ac.uk/

The online version of the original article can be found at http:// dx.doi.org/10.1007/s11517-006-0127-0.

R. Wilders $(\square)$

Department of Physiology, Academic Medical Center,

University of Amsterdam, Meibergdreef 15,

1105 AZ Amsterdam, The Netherlands

e-mail: r.wilders@amc.uva.nl 